\title{
The catching efficiency of light traps and morphometric characteristics of the native species from Barito river, Indonesia
}

\author{
Ahmadi (1D \\ Faculty of Marine and Fisheries, Lambung Mangkurat University, Indonesia 70714 \\ ahmadi@unlam.ac.id
}

Received date: 01.08.2017 Accepted date: 16.01.2018

How to cite this paper:

Ahmadi (2018). The catching efficiency of light traps and morphometric characteristics of the native species from Barito river, Indonesia. Ege Journal of Fisheries and Aquatic Sciences, 35(1): 63-72. doi:10.12714/egejfas.2018.35.1.11

\begin{abstract}
Various fishing gears are being used for harvesting fish and shrimp in Barito River, Indonesia. However, the use of lighted traps is still poorly studied. A set of fishing gears associated with light emitting diode (LED) and incandescent lamps was used as sampling tools. The trials consisted of 113-trap hauls/lamp type using 1-night submersion time of $15 \mathrm{~h}$. The light traps were standardized to a catch per unit effort (CPUE). The light traps sampling accounted for 397 specimens assigned to 11 species of 7 families. There was highly significant difference in the number of catches between shrimp and fish ( $P<0.001)$. Shrimp sizes ranged of 24-85 mm total length and 0.3-10 g weight, while for fish 27-310 mm and 0.4-101 g. Yellow and red LED light traps seemed to be effective in catching Macrobrachium rosenbergii as well as white LED ones for Oxyeleotris marmorata. Both species solely showed positive allometric growth type $(b=3.42$ and 3.28$)$, while other species displayed negative allometric growth pattern $(b=0.82-2.71)$ with the condition factor $(K)$ values ranged of $0.36-1.56$. A new native species Macrobrachium sp. were found and considered as multichromatic species. The size and shape of the light traps did not affect number of catch. The mean CPUEs for incandescent and LED light traps were $0.07 \pm 0.06$ and $0.13 \pm 0.20$ fish net- 1 night- 1 . No significant difference in the relative catching efficiency between both light trap types was observed.
\end{abstract}

Keywords: Allometric growth, incandescent lamp, LED lamp, Macrobrachium sp., condition factor, traps, Barito River

\section{INTRODUCTION}

South Kalimantan is one of the five provinces in Kalimantan (formerly called Borneo) with capital city of Banjarmasin. It is bordered with East Kalimantan at the north, with Makassar Strait at the east, with Java Sea at the south and with West Kalimantan and Central Kalimantan at the west. South Kalimantan is also often known as Province with a thousandriver where the Barito River is the largest and the longest river in Indonesia with more than $6.000 \mathrm{~km}$ long. Barito River has the depths of 8-10 m and a width of $400-750 \mathrm{~m}$. It is the main river that is mutually associated with creeks and swamps vicinity; about $90 \%$ are still affected by the tidal Java Sea. The Barito River allows for transportation, drinking water sources, floating market and fisheries activities. A great attention has been devoted by academicians and researchers to expose the characteristic habitats and fish species in the river (MacKinnon et al., 1996; Prasetyo et al., 2005; Asyari, 2006), the abundance and diversity of plankton types (Rahman, 2008), as well as fishing activities (Utomo and Prasetyo, 2005; Rupawan, 2006; Utomo and Asyari, 2007; Rosadi et al., 2016).

Local people usually collect fish and shrimp in Barito River using hook and line, gill net, lift net and traps, among others. In the past, a total of 350 species was found in this river, but now it is estimated only about 150 species (Hortle, 1995). Prasetyo and Asyari (2003) reported that the number of fish species in this river was to become 140 species. Some important fish species like Arowana Scleropages formosus, clown knifefish Notopterus chitala, mad barb Leptobarbus hoevenii and the greater bony lipped barb Osteocheilus melanopleura seemed to disappear from the river. They are extremely vulnerable to the destructive fishing as well as water pollution from plywood industry and dockyard. Therefore, fishing technology development that environmentally friendly and efficient, should be promoted. The use of lights would be a promising option for responsible fishing practices.

Light trap is one of the good examples for collecting many species of different habitats when other fishing gear like towed net are not useful (Brogan, 1994; Hernandez and Shaw, 2003). The LED lamp is one of the most recent advance lamps being promoted in light fishing-based fisheries (Yamashita et al., 2012; Hua and Xing 2013; Mills et al., 2014; Puspito et al., 2015) instead of incandescent, halogen, and metal halide illuminations (Baskoro et al., 2002; Matsushita et al., 2012) or chemical light sticks (Kissick, 1993; Marchetti et al., 2004). As for the difference in light sources, each lamp has its unique optics and intensity output even same electrical power use.

The use of lighted traps in Barito River is still poorly studied (Ahmadi, 2012). Therefore, several potential biases should be 
deliberated before light traps ready to be used quantitatively. We performed this study to address the following questions, e.g. how effective traps with low-powered lights applied in highly turbid water? What species will be attracted to the light traps? Are individual species collected in different numbers using specific colors/relative intensities of light? Do size and shape of the light trap affect number of catch? We updated and extended database on the light traps testing to get more knowledge in this area of study. The information obtained may be useful for both commercial purpose and fisheries management.

\section{MATERIALS AND METHODS}

\section{Study area}

Trapping experiments with lights were carried out in Barito River of South Kalimantan Province (Figure 1), located on $03^{\circ} 19^{\prime} \mathrm{S} 114^{\circ} 34^{\prime} \mathrm{E}$ and $03^{\circ} 20^{\prime} \mathrm{S} 114^{\circ} 36^{\prime} \mathrm{E}$ determined with the GPS 60 (Garmin Co. Ltd., Taiwan).

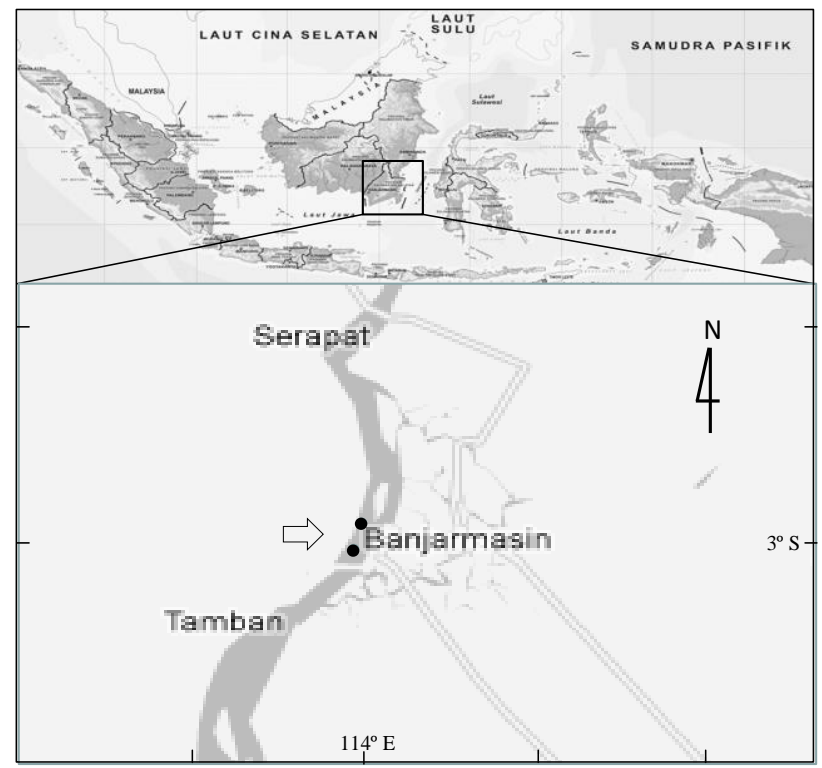

Figure 1. The map showing the study sites for trapping experiment with lights in Barito River

The experimental conditions encompassed highly turbid water (total suspended solids ranged from 182-567 $\mathrm{mg} \mathrm{L}^{-1}$ ), slow flowing, blocked water, and rarely vegetated habitat with water depths from 2-4 $\mathrm{m}$. The transparency of water varied from 45 to $55 \mathrm{~cm}$ (Secchi-disk reading at noon). The surface water temperature was recorded daily and ranged from 27 to $29^{\circ} \mathrm{C}$ throughout the trials. The experimental designs were described as follows:

\section{Traps and lamps used}

Experiment 1: Collapsible trap fishing with different light intensities of incandescent lamps. The four collapsible boxshaped traps were constructed with iron rod frame $(80 \times 60 \times 28$ $\mathrm{cm})$, covered with polyethylene netting and had two slit all-web entrances at the ends consisting of two netting panels forming a horizontal "V" with $58 \mathrm{~cm}$ slit at the narrow end (Kagotoku Shiroyama Kenmousha, Ise, Japan). Each of the four traps has one incandescent lamp. The lamps used were (i) Japanese squid fishing tackles (Yo-zuri Co. Ltd. Japan) consisting of (squid fishing light/SIL-1 $(10 \times 3 \mathrm{~cm} ; 0.45 \mathrm{~W})$ and SIL-2 $(16 \times 3$ $\mathrm{cm} ; 0.9 \mathrm{~W}$ ) powered by 1.5 and $3.0 \mathrm{~V}$ dry-cell batteries respectively, and, (ii) acrylic box-shaped lamps consisting of DIM (dimmed) and LIGHT, of which a $4.5 \mathrm{~W}$ lamp was placed inside a waterproof acrylic box $(14[8 \square 15 \mathrm{~cm})$ generated by $6 \mathrm{~V}$ dry-cell batteries. For DIM, the walls of the box were lined with a white-paper. Light intensity of each lamp was $215 \mathrm{Ix}$ (SIL-1), 398 Ix (SIL-2), 1010 Ix (DIM) and 2050 Ix (LIGHT) determined in air using an illuminometer (IM-2D, Topcon, Ltd. Tokyo).

Experiment 2: Collapsible trap fishing with different coloured incandescent or LED lamps. Five collapsible boxshaped traps were modified in their funnel entrances by replacing the two slit all-web entrances at the ends with two open slackness nylon monofilaments $23 \mathrm{~mm}$ mesh size. Additional net bag was placed at the bottom of the trap to prevent juveniles from dropping. Each of the five traps was assigned with one colour of LED Torpedo flashers $(24 \times 5 \mathrm{~cm}$, Yuli Co. Ltd. China) or one colour of incandescent lamps YL/YS-1 $(22 \times 5 \mathrm{~cm}$, Yuli Co. Ltd. China), consisting of blue, green, yellow, red and extra white.

Experiment 3: Wire-square trap fishing with different coloured LED lamps. Five wire-square traps were made of ironwire frame $(25 \times 25 \times 22 \mathrm{~cm})$, covered with black $3 / 5$ inch hexagonal mesh wire (16 gauge PVC-coated wire), and had four entry funnels located on each side with a $5 \mathrm{~cm}$ inside ring entrance. A trap door on top $(23 \times 24 \mathrm{~cm})$ was used to release the catches. Each of the five traps was assigned with one colour of LEDs. Each colour (blue, green, yellow, red and extra white) was placed inside the squid lamp case (SIL-2) powered by $3 \mathrm{~V}$ dry-cell batteries $(0.06 \mathrm{~W})$. Light intensity of LEDs was set at equal quanta intensities by placing a grey fibreglass window screen (Dio Chemicals, Ltd., Tokyo) inside of the lamp to standardize the lights used.

Experiment 4: The acrylic-square trap fishing with different coloured LED lamps for sampling juvenile species. Five acrylicsquare traps were constructed with $3 \mathrm{~mm}$ acrylic plates and had 8 entrance slits with $1 \mathrm{~cm}$ wide opening on each side. The acrylic plates were attached vertically with two sheets of PVC $(24 \times 24 \mathrm{~cm})$ top-down and reinforced with four iron rods $(25 \mathrm{~cm}$ long) on each corner. The trap was equipped with two floats at the surface, four wire-stairways $(23 \times 23 \mathrm{~cm})$ attached to lower part of PVC sheet on each side and a collection wire-jar at the bottom $(18 \times 18 \times 7 \mathrm{~cm})$. A lamp was placed downright in the middle of trap. Each of the five traps was assigned with one colour of LEDs following the same procedure in Experiment 1. Traps and lamps used in the present study are shown in Fig 2.

Experiment 5: Various traps fishing with the white LED and incandescent lamps. Four traps with different sizes and shapes were investigated. These traps were: (1) PVC box-shaped trap: 
PVC rod frame $(67 \times 53 \times 20 \mathrm{~cm})$ covered with black $150 \mathrm{~mm}$ hexagonal mesh wire ( 16 gauge PVC-coated wires); ten entry funnels are located on each side of the trap with a $5.2 \mathrm{~cm}$ inside ring entrance; (2) Wire fish trap: heart-shaped, $45 \mathrm{~cm}$ high and $40 \mathrm{~cm}$ wide, with $1.2 \mathrm{~cm}$ square mesh wire and $2.5 \mathrm{~cm}$ wide opening of entrance slit; (3) Bamboo fish trap: heart-shaped, 42 $\mathrm{cm}$ high and $30 \mathrm{~cm}$ wide with horizontal gap $1.5 \mathrm{~cm}$ and $2.5 \mathrm{~cm}$ wide opening of entrance slit; and (4) Minnow nets: cylindricalshaped, $60 \mathrm{~cm}$ long by $30 \mathrm{~cm}$ wide, covered with $1.3 \mathrm{~cm}$ polyethylene netting and $7 \mathrm{~cm}$ inside the ring entrance. Each of the four traps was associated with $0.06 \mathrm{~W}$ white LED or $1.5 \mathrm{~W}$ incandescent squid fishing lamp (SIL-2; Experiment 1).

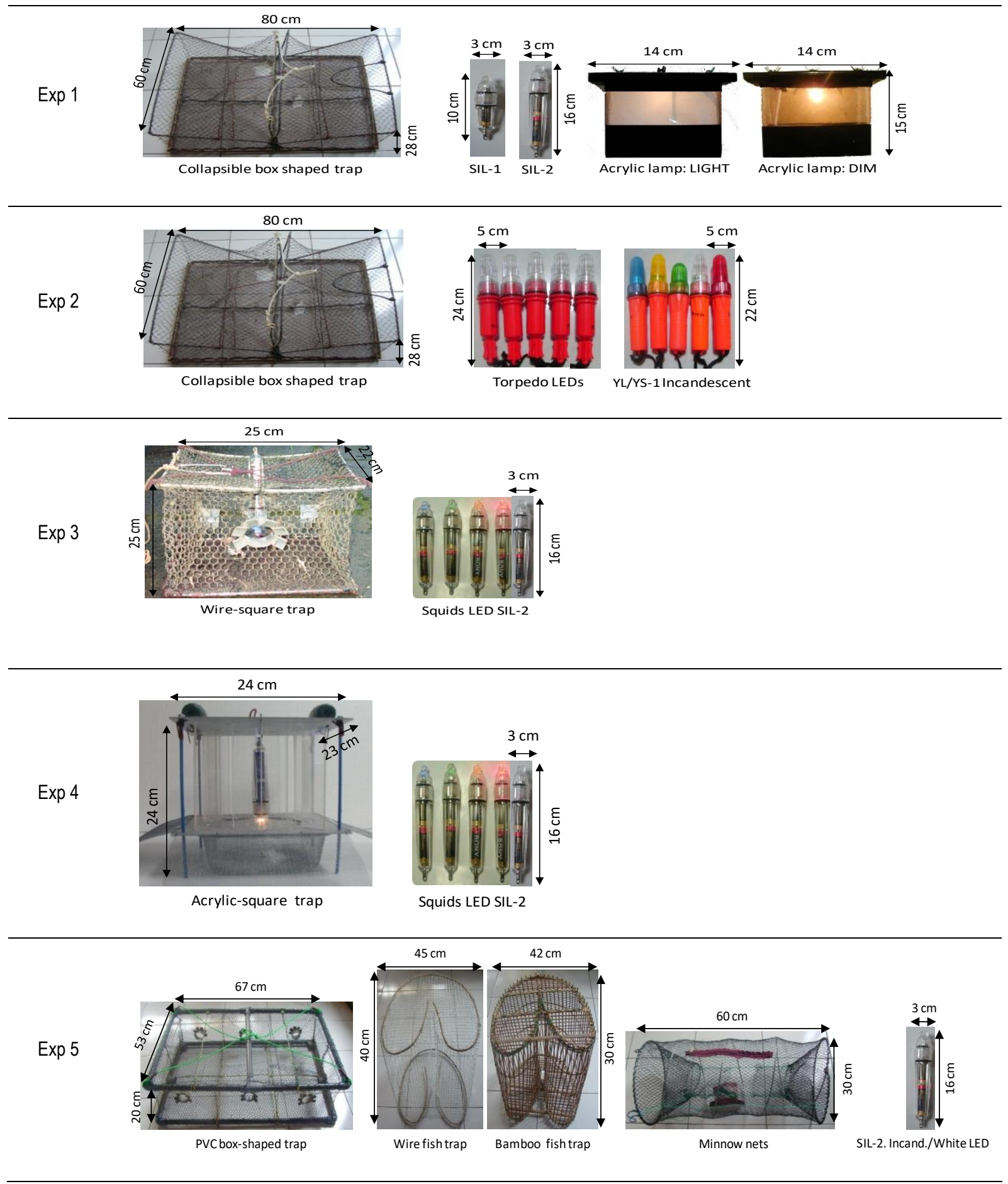

Figure 2. The traps and lamps used to sample shrimps and fish from Barito River 


\section{Sampling and data analysis}

The light traps with constant light pattern were deployed randomly at the bottom of the riverbank and illumination began $1 \mathrm{~h}$ before sunset and retrieved the next morning. On each sampling date, each trap was separated from the others about $2.5 \mathrm{~m}$ to minimize any significant light contamination between traps. Such trap arrangement was considered sufficient for the existing turbidity conditions and illumination intensities. Each experimental group was repeatedly used for 6-night fishing The trials consisted of 113-trap hauls/lamp type using 1-night soaking time of $15 \mathrm{~h}$. Both incandescent and LED light traps were standardized to a catch per unit effort (CPUE) of total catch per night-trip. After retrieval, the catches were counted and identified for species and sex, and measured for total length $(\mathrm{TL})$ in $\mathrm{mm}$ and weight $(\mathrm{W})$ in $\mathrm{g}$.

The length-weight relationships of species were estimated by using the equation: $W={ }_{a} L^{b}$. The parameters $a$ (intercept) and $b$ (slope) were estimated by linear regression of the transformed equation: $\log W=\log a+b{ }^{*} \log L$. The $b$ values were calculated to find out whether the species was growing allometrically or isometrically. The exponent $b$ values of lengthweight relationship of species were compared to the hypothetical value of 3 . When the $b$ value is greater than 3 indicating positive allometric, less than 3 is negative allometric, and equal to 3 is isometric (Anderson and Neumann, 1996).
Positive allometic means that weight increases more than length. Negative allometric means that length increases more than weight. Isometric means that length and weight are growing at the same rate. The parameter $b$ is also known as allometry coefficient that has an important biological meaning, indicating the rate of weight gain relative to growth in length. The condition factor of species was calculated using Fulton's condition factor, $K=100 \mathrm{~W} / \mathrm{L}^{3}$ (Gayanilo and Pauly, 1997), where: $L=$ total length $(\mathrm{cm})$ and $W=$ weight $(\mathrm{g})$. In addition, the Mann-Whitney test was employed to compare the number of catch between two light traps. Kruskal-Wallis test was used to investigate if there were significant differences in the total catches among the lighted traps. A post-hoc analysis test was performed using the Multiple Comparison to see which catch differed significantly among the traps. Lastly the t-test was used to evaluate the relative catching efficiency of incandescent and LED light traps across all trials. All tests were analysed at the 0.05 level of significance using SPSS-16 software.

\section{RESULTS}

A total of 397 native specimens belong to 11 species comprised 344 shrimps ( 1 family) and 53 fishes (6 families) collected from a series of trapping experiments with lights in Barito River as presented in Table 1.

Table 1. Catch species composition sampled from Barito River using the lighted traps.

\begin{tabular}{|c|c|c|c|c|c|c|c|c|}
\hline \multirow[t]{2}{*}{ Group/Family } & \multirow[t]{2}{*}{ Species } & \multicolumn{4}{|c|}{ Incandescent lamps } & \multicolumn{2}{|c|}{ LED lamps } & \multirow{2}{*}{$\begin{array}{l}\text { Total } \\
\text { catch }\end{array}$} \\
\hline & & Ordinary & $\%$ & Colour & $\%$ & Colour & $\%$ & \\
\hline Shrimps & & & & & & & & 344 \\
\hline Palaemonidae & Macrobrachium sp & 65 & 19 & 51 & 15 & 223 & 66 & 339 \\
\hline Palaemonidae & M. rosenbergii & 0 & 0 & 1 & 20 & 4 & 80 & 5 \\
\hline Fish & & & & & & & & 53 \\
\hline Gobiidae & Glossogobius giuris & 5 & 26 & 4 & 21 & 10 & 53 & 19 \\
\hline Eleotridae & Oxyeoleotris urophthalmus & 4 & 24 & 0 & 0 & 13 & 76 & 17 \\
\hline Eleotridae & Oxyeoleotris marmorata & 1 & 14 & 1 & 14 & 5 & 71 & 7 \\
\hline Pleuronectidae & Flounder pleuronectes & 2 & 67 & 1 & 33 & 0 & 0 & 3 \\
\hline Mastacembelidae & Mastacembelus erythrotaenia & 1 & 33 & 1 & 33 & 1 & 33 & 3 \\
\hline Cyprinidae & Puntioplites bulu & 1 & 50 & 0 & 0 & 1 & 50 & 2 \\
\hline Cyprinidae & Osteochilus melanopleura & 0 & 0 & 1 & 100 & 0 & 0 & 1 \\
\hline Bagridae & Mystus gulio & 1 & 100 & 0 & 0 & 0 & 0 & 1 \\
\hline Crab & & & & & & & & 2 \\
\hline Parathelphusidae & Parathelphusa convexa & 0 & 0 & 0 & 0 & 2 & 100 & 2 \\
\hline
\end{tabular}

The shrimp was dominated by the long arms shrimp Macrobrachium sp. (98.55\%) with the sizes ranged of 24-85 $\mathrm{mm} \mathrm{TL}(58.1 \pm 15.15 \mathrm{~mm})$ and $0.3-10 \mathrm{~g} \mathrm{~W}(3.2 \pm 2.57 \mathrm{~g})$, and the rest of catch was giant river prawn M. rosenbergii (1.45\%) with the sizes ranged of $71-75 \mathrm{~mm}$ TL $(56.8 \pm 17.63 \mathrm{~mm})$ and $0.5-5$ $\mathrm{g}(2.6 \pm 2.27 \mathrm{~g})$. The fish comprised tank goby Glossogobius giuris $(35.85 \%, 135.7 \pm 19.68 \mathrm{~mm} \mathrm{TL}$, and $31.3 \pm 9.08 \mathrm{~g}$ ), Sinuous gudgeon Oxyeleotris urophthalmus (32.08\%, $123.6 \pm 42.06 \mathrm{~mm} \mathrm{TL}$, and $29.5 \pm 23.48 \mathrm{~g}$ ), Marble gudgeon Oxyeleotris marmorata $(13.21 \%, 140.5 \pm 23.35 \mathrm{~mm} \mathrm{TL}$, and
$41.0 \pm 22.82 \mathrm{~g}$ ), Flatfish Flounder pleuronectes (5.66 \%, $100.7 \pm 37.90 \mathrm{~mm}$ TL and $17.0 \pm 14.11 \mathrm{~g}$ ), Spotted fire eel Mastacembelus erythrotaenia $(5.66 \%, 278.3 \pm 38.84 \mathrm{~mm}$ TL, and $76.7 \pm 22.05 \mathrm{~g}$ ), Bulu barb Puntioplites bulu (3.77 \%, $70.1 \pm 14.14 \mathrm{~mm}$ TL and $2.5 \pm 2.12 \mathrm{~g}$ ), greater bony lipped barb Osteochilus melanopleura (1.89 \%, $170 \mathrm{~mm} \mathrm{TL}$, and $64 \mathrm{~g})$, Long whiskers catfish Mystus gulio $(1.92 \%, 40 \mathrm{~mm}$, and $1 \mathrm{~g})$. The sizes of fish captured varied from 27 to $310 \mathrm{~mm} \mathrm{TL}$ and from 0.4 to $101 \mathrm{~g}$. The body sizes of each species caught are given in Table 2.The four collapsible box-shaped traps fishing 
with different light intensities of incandescent lamps in Experiment 1 were evaluated. A total of 46 specimens were collected from this trial. The CPUEs of individual trap ranged from $0.14 \pm 0.16$ to $0.44 \pm 0.46$ fish net $^{-1}$ night $^{-1}$ (Table 3 ). There was no significant difference in the total number of catches among the four traps $\left(X^{2}=1.184, \mathrm{df}=3, P>0.05\right)$. The overall, the traps had some success in catching Macrobrachium sp (total 39), Glossogobius giuris (5), Mystus gulio (1) and Mastacembelus erythrotaenia (1). The LIGHT and DIM traps collected the same number of Macrobrachium sp. (13) were observed. The average total length of Macrobrachium $\mathrm{sp}$ ranged from $63.8 \pm 21.24 \mathrm{~mm}$ to $73.3 \pm 3.06 \mathrm{~mm}$, while the average weight varied from $5.4 \pm 3.84 \mathrm{~g}$ to $6.4 \pm 2.08 \mathrm{~g}$.

The five collapsible box-shaped traps containing different coloured incandescent or LED lamps were investigated in Experiment 2. The light traps sampling accounted for 211 specimens (total 60 for incandescent lamp and 151 for LED lamp). The CPUEs of incandescent light trap ranged from $0.78 \pm 0.51$ to $2.78 \pm 1.39$ fish net $^{-1}$ night $^{-1}$, while for LED light trap ranged from $3.00 \pm 4.33$ to $3.67 \pm 6.06$ fish net $^{-1}$ night $^{-1}$ (Table 3). There were no statistically significant differences in the total number of catches among the five traps $\left(X^{2}=2.970\right.$, $\mathrm{df}=4, P>0.05)$. The colour of lights had strong effects on the number of shrimp and fish collected especially Macrobrachium sp. and Glossogobius giuris. The use of traps with coloured LED lamps seemed to be more effective in catching Macrobrachium sp. (total 138) than incandescent ones (total 51) $(T=1.412, P<0.05)$. The average weight of catches for incandescent and LED lighted traps was $5.22 \pm 11.64 \mathrm{~g}$ and $5.32 \pm 13.17 \mathrm{~g}$ respectively. Furthermore, sex ratio of male to female Macrobrachium sp. was 1:2.3 indicating many more females caught than males. We collected 48 egg-bearing females during the whole sampling period. From the length measurement, male chelae were 1.5 times of its total length and 1.3 times for females of the same body size.

Table 2. Descriptive statistic of length-weight relationships of catch species sampled from Barito River. $N=$ number of catch, $T L=$ total length, $\mathrm{W}=$ weight, $\mathrm{a}=$ intercept, $\mathrm{b}=$ slope, $\mathrm{R}^{2}=$ coefficient of determination, $\mathrm{K}=$ condition factor.

\begin{tabular}{|c|c|c|c|c|c|c|c|c|c|c|c|c|}
\hline \multirow{2}{*}{ Species } & \multirow{2}{*}{$\mathrm{N}$} & \multicolumn{3}{|c|}{$\mathrm{TL}(\mathrm{mm})$} & \multicolumn{3}{|c|}{$W(g)$} & \multirow{2}{*}{$\mathrm{W} / \mathrm{TL}$} & & & \multirow{2}{*}{$\mathrm{R}^{2}$} & \multirow[t]{2}{*}{$K$} \\
\hline & & Min & $\operatorname{Max}$ & Mean $\pm S D$ & Min & Max & Mean $\pm S D$ & & & & & \\
\hline Macrobrachium sp & 339 & 24 & 85 & $58.1 \pm 15.15$ & 0.3 & 10 & $3.2 \pm 2.57$ & 0.06 & $10^{-5}$ & 3.04 & 0.85 & 1.31 \\
\hline Macrobrachium rosenbergii & 5 & 38 & 74 & $56.8 \pm 17.63$ & 0.5 & 5 & $2.6 \pm 2.27$ & 0.05 & $2 \times 10^{-6}$ & 3.42 & 0.97 & 1.05 \\
\hline Glossogobius giuris & 19 & 95 & 165 & $135.7 \pm 19.68$ & 9 & 44 & $31.3 \pm 9.08$ & 0.23 & $10^{-4}$ & 2.51 & 0.90 & 1.15 \\
\hline Oxyeoleotris urophthalmus & 17 & 27 & 194 & $123.6 \pm 42.06$ & 0.4 & 90 & $29.5 \pm 23.48$ & 0.24 & $5 \times 10^{-5}$ & 2.71 & 0.99 & 1.29 \\
\hline Oxyeoleotris marmorata & 7 & 115 & 172 & $140.5 \pm 23.35$ & 19 & 77 & $41.0 \pm 22.82$ & 0.29 & $3 \times 10^{-6}$ & 3.28 & 0.99 & 1.36 \\
\hline Flounder pleuronectes & 3 & 60 & 135 & $100.7 \pm 37.90$ & 4 & 32 & $17.0 \pm 14.11$ & 0.17 & $10^{-4}$ & 2.51 & 0.99 & 1.46 \\
\hline Mastacembelus erythrotaenia & 3 & 235 & 310 & $278.3 \pm 38.84$ & 58 & 101 & $76.7 \pm 22.05$ & 0.28 & $4 \times 10^{-3}$ & 1.75 & 0.81 & 0.36 \\
\hline Puntioplites bulu & 2 & 60 & 80 & $70.1 \pm 14.14$ & 2 & 5 & $2.5 \pm 2.12$ & 0.04 & 2.84 & 0.82 & 1.00 & 0.95 \\
\hline Osteochilus melanopleura & 1 & 170 & 170 & 170 & 64 & 64 & 64 & 0.38 & N/A & N/A & N/A & 1.30 \\
\hline Mystus gulio & 1 & 40 & 40 & 40 & 1 & 1 & 1 & 0.03 & N/A & NA & N/A & 1.56 \\
\hline
\end{tabular}

The similar results were demonstrated in Experiment 3. There were no significant differences in the total number of catches among the five wire-square traps with different coloured LED lamps $\left(X^{2}=1.368, \mathrm{df}=4, P>0.05\right)$. A total of 82 individuals collected from lighted traps. The CPUEs of individual trap ranged from $0.31 \pm 0.19$ to $0.50 \pm 0.60$ fish net ${ }^{1}$ night $^{-1}$ (Table 3). The shrimp was dominated by Macrobrachium sp. (total 65), while the fish was represented by Oxyeleotris urophthalmus (10). The least number of catch was Glossogobius giuris (1) caught by red trap. The average weight of catches was $7.84 \pm 9.11 \mathrm{~g}$.

Unexpected results were found in Experiment 4 where the trials with the five acrylic-square traps containing different coloured LED lamps had no success in catching both fish and shrimp juveniles. The only three juveniles of Macrobrachium sp. were collected from the blue and yellow light traps due to the considerable breakage on the entrance slits of traps, which allowed the animals to escape from the traps. The mean weight of the catches was $2.27 \pm 2.37 \mathrm{~g}$. Total CPUE obtained was $0.60 \pm 0.00$ shrimp net $^{-1}$ night $^{-1}$ (Table 3 ).

The performance of PVC box-shaped trap, wire fish trap, bamboo fish trap, and minnow nets associated with incandescent lamp (SIL-2) or white LED was examined in Experiment 5. There were no significant differences in the total catch among the respective four traps $\left(X^{2}{ }_{\text {LED }}=1.737\right.$, $\left.X^{2}{ }{ }_{N C}=6.978, d f=3, P>0.05\right)$. Overall, the minnow nets were most effective among the traps (total 14 for LED lighted trap and 20 for incandescent ones) especially for catching Macrobrachium $\mathrm{sp}$. The other traps collected less number of catch for all trials. The mean weight of catches for LED and incandescent light traps were $7.33 \pm 8.02 \mathrm{~g}$ and $7.15 \pm 8.63 \mathrm{~g}$ respectively. The mean CPUEs of incandescent light trap ranged from $2.22 \pm 1.95$ to $0.89 \pm 0.51$ fish net $^{-1}$ night $^{-1}$, while for LED light trap ranged from $0.22 \pm 0.19$ to $1.56 \pm 0.19$ fish net $^{-1}$ night $^{-1}$ (Table 3). 
Table 3. Total catch and Mean \pm SD of CPUEs of each light trap group by experimental order

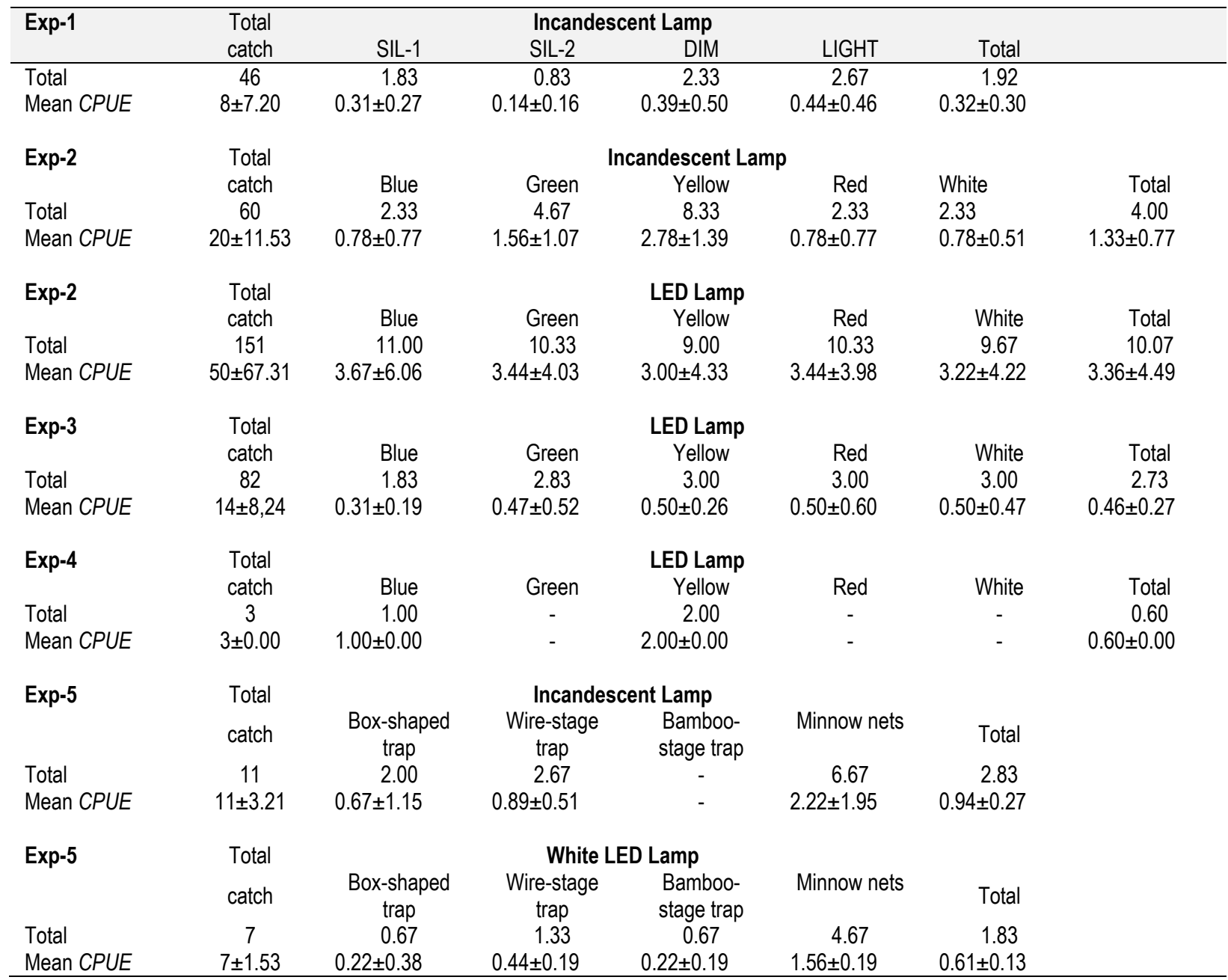

Table 4. The daily total catch and CPUEs of Incandescent and LED light traps

\begin{tabular}{|c|c|c|c|c|}
\hline \multirow{2}{*}{ Sampling Day } & \multicolumn{2}{|c|}{ Daily Total Catch } & \multicolumn{2}{|c|}{ Daily CPUE } \\
\hline & Incandescent & LED & Incandescent & LED \\
\hline 1 & 18 & 28 & 0.115 & 0.167 \\
\hline 2 & 15 & 16 & 0.096 & 0.095 \\
\hline 3 & 7 & 16 & 0.045 & 0.095 \\
\hline 4 & 3 & 6 & 0.019 & 0.036 \\
\hline 5 & 2 & 8 & 0.013 & 0.048 \\
\hline 6 & 1 & 8 & 0.006 & 0.048 \\
\hline 7 & 9 & 6 & 0.058 & 0.036 \\
\hline 8 & 15 & 9 & 0.096 & 0.054 \\
\hline 9 & 10 & 7 & 0.064 & 0.042 \\
\hline 10 & 9 & 14 & 0.058 & 0.083 \\
\hline 11 & 19 & 9 & 0.122 & 0.054 \\
\hline 12 & 32 & 128 & 0.205 & 0.762 \\
\hline Total & 140 & 255 & 0.897 & 1.518 \\
\hline Mean \pm SD & $12 \pm 8.79$ & $21 \pm 34.20$ & $0.07 \pm 0.06$ & $0.13 \pm 0.20$ \\
\hline$\Sigma$ no of trap & 13 & 14 & - & - \\
\hline$\Sigma$ fishing trial & 12 & 12 & - & - \\
\hline
\end{tabular}


The results clearly confirmed that Macrobrachium sp. showed isometric growth type $(b=3.04)$, while $M$. rosenbergii exhibited positive allometric growth pattern $(b=3.42)$. The $\mathrm{R}^{2}$ values of 0.85 and 0.97 indicated that variations in weight of shrimp were influenced by variation in the length of shrimp by $85 \%$ and $97 \%$ respectively. The $\mathrm{K}$ values (condition factor) for both shrimps were 1.31 and 1.05 respectively. Among the fish group, the only Oxyeleotris marmorata displayed positive allometric growth pattern $(b=3.28, \mathrm{~K}=1.36)$, while the other fish species showed negative allometric growth pattern $(b=1.75$ 2.71 and $K=0.36-1.56)$. The $R^{2}$ values ranged of $0.81-1.00$ which meant that variations in weight of fish were influenced by variation in the length of fish by $81-100 \%$ (Table 2).

The relationship between the relative catching efficiency and the ratio of CPUEs to lamp type of incandescent and LED light traps were expressed in the following logarithmic equations: $y$ $=0.1672 \operatorname{Ln}(x)+1.019\left(R^{2}=0.8932\right)$ and $y=0.1777 \operatorname{Ln}(x)+0.9847$ $\left(R^{2}=0.7266\right)$, respectively (Figure 3$)$. Although the mean CPUE of LED light traps $\left(0.13 \pm 0.20\right.$ fish net $^{-1}$ night $\left.^{-1}\right)$ was higher than that of incandescent light traps $\left(0.07 \pm 0.06\right.$ fish net $^{-1}$ night $\left.^{-1}\right)$, however, no statistically significant difference was observed $(\mathrm{t}=-0.848, \mathrm{df}=22, P<0.05)$. The comparative daily total catch and CPUE of both light traps are given in Table 4

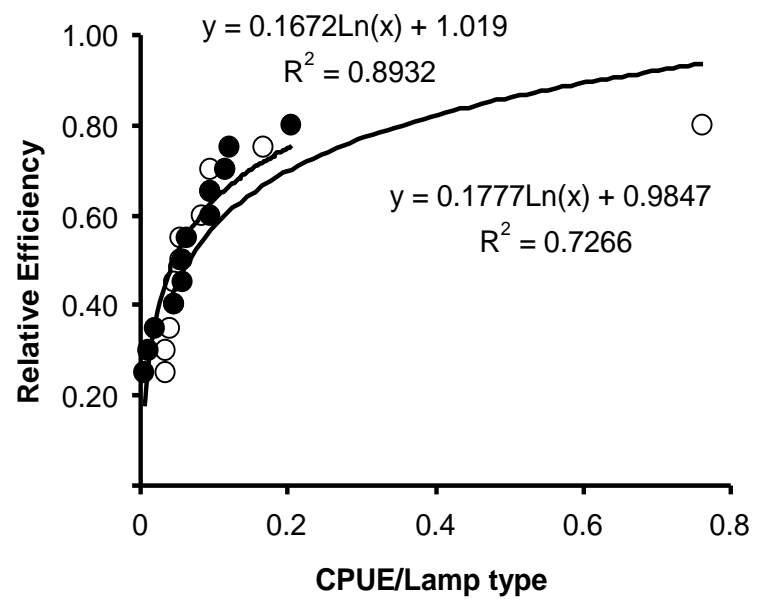

Figure 3. The relationship between relative catching efficiency and the ratio of daily CPUE to lamp type of incandescent and LED (O) light traps

\section{DISCUSSION}

Fish and other aquatic species have colour receptions in their eyes that could recognize various intensities of light that lead to their aggregation in the lighted areas (Arimoto et al., 2010). The present study clearly demonstrates that trapping with low-powered underwater lamps are adaptable applicable in high turbid water of Barito River. Data on phototactic response showed that the colours or relative light intensity of incandescent and LED lamps uses in this study had strong effects on the number of catches sampled, where LED light traps are outperformed to the incandescent ones. It is a good starting point in view of commercial purposes where yellow and red LED light traps seemed to be effective in catching $M$. rosenbergii, as well as white ones for catching Oxyeleotris marmorata. In this case, $M$. rosenbergii were less active in responding to the lights compared to Macrobrachium sp. of the same genus. Among the catches, the only $M$. rosenbergii $(b=3.42)$ and Oxyeleotris marmorata $(b=3.28)$ showed positive allometric growth type. This means that the both species are considered healthy and in good shape. Kunda et al. (2008) reported isometric growth $(b=3.075)$ of $M$. rosenbergii in rice field of India. While Sampaio and Valenti (1996) observed high $b$ value of 3.43 (positive allometric) for $M$. rosenbergii under culture environment in Brazil. Wider ranges of size need to be investigated in order to determine how the relationships change with shrimp size or life stage (Chow and Sandifer, 1991). The ratios of W/TL for Macrobrachium sp. (0.06) and M. rosenbergii $(0.05)$ in the present study (Table 5) were more or less found in other shrimp species from different geographical areas (Okayi and lyorkyaa, 2004; Nwosu and Wolfi, 2006; Lalrinsanga et al., 2012; Gopalakrishnan et al., 2014; Gautam et al., 2014; Wong et al., 2015). Compared to other species such as Macrobrachium felicinium and Atya gabonensis in Nigeria (Okayi and lyorkyaa (2004), Metapenaeus monoceros and Penaeus monodon in India (Dineshbabu, 2006; Gopalakrishnan et al., 2014), Macrobrachium lamarrei in Bangladesh (Ara et al., 2014) and Acetes indicus in Malaysia (Wong et al., 2015), these ratios were lower than those presented in this research.

In the current study, the $b$ values were generally in good agreement with the results obtained from other geographical areas (Table 5). Variation in $b$ values of animals living in this river will also help understand why certain species are able to survive in the waters. For example, Macrobrachium sp. was abundantly found in this river and they could be considered as multichromatic species because of showing photopositive for all colours. They are most likely support higher biomass in the aquatic food web as the whole. Experimental evidence showed that female-biased attraction to the lights. The sex ratio of male to female was $1: 1.1$, indicating that females were more responsive to the tested colours than males over trapping experiment periods. This implies that light traps could be potentially used for broodstock purposes, especially to collect them from the wild. About $40 \%$ of total female caught by light traps was the egg-bearing females. In many cases, females carrying the eggs are usually inactive during the breeding season and are not attracted to food or bait (Richards et al., 1996; Holdich, 2002; Faller et al., 2006), however, the light traps can do. As for comparison, it is interestingly noted that at the same body size $(72 \mathrm{~mm})$, the male of Macrobrachium sp. (112 $\mathrm{mm}$ long) has chelae twice longer than that of $M$. Australiense (51 mm; Short, 2000). 
Table 5. Comparative parameters of length and weight relationship of Macrobrachium sp. from Barito River and other shrimp species from different geographical areas. $N=$ number of catch, $T L=$ total length, $W=$ weight, $a=$ intercept, $b=$ slope,$R^{2}=$ coefficient of determination, $A+=$ positive allometric, $A$ - = negative allometric, $I=$ isometric

\begin{tabular}{|c|c|c|c|c|c|c|c|c|}
\hline Species (pooled) & $\mathbf{N}$ & W/TL & a & b & $\mathbf{R}^{2}$ & $\begin{array}{c}\text { Growth } \\
\text { Type }\end{array}$ & Country & References \\
\hline Macrobrachium sp & 339 & 0.06 & $10^{-5}$ & 3.040 & 0.850 & 1 & Indonesia & Present study \\
\hline M. rosenbergii & 5 & 0.05 & $2 \times 10^{-6}$ & 3.420 & 0.970 & $A+$ & Indonesia & Present study \\
\hline M. rosenbergii & 733 & 0.00 & $8.8 \times 10^{-2}$ & 3.389 & 0.949 & $A^{+}$ & India & Lalrinsanga et al. (2012) \\
\hline M. lamarrei & 1018 & 0.13 & $10^{-3}$ & 2.845 & 0.945 & A- & Bangladesh & Ara et al. (2014) \\
\hline M. felicinium & 55 & 1.04 & $1.6 \times 10^{-3}$ & 3.003 & 0.998 & I & Nigeria & Okayi \& lyorkyaa (2004) \\
\hline Atya gabonensis & 150 & 1.74 & $1.4 \times 10^{-2}$ & 2.989 & 0.990 & I & Nigeria & Okayi \& lyorkyaa (2004) \\
\hline M. vollenhovenii & 1069 & 0.00 & 0.000 & 3.483 & 0.993 & $A+$ & Nigeria & Nwosu \& Wolfi (2006) \\
\hline Metapenaeus monoceros & 363 & 0.34 & $6 \times 10^{-3}$ & 3.085 & 0.907 & I & India & Dineshbabu (2006) \\
\hline Litopenaeus vannamei & 313 & 0.02 & $6 \times 10^{-4}$ & 3.458 & 0.999 & $A^{+}$ & India & Gautam et al. (2014) \\
\hline Penaeus monodon & 633 & 0.66 & -1.340 & 2.609 & 0.778 & A- & India & Uddin et al. (2016) \\
\hline P. monodon & 873 & 1.59 & -1.811 & 2.721 & 0.707 & A- & India & $\begin{array}{l}\text { Gopalakrishnan et al. } \\
\text { (2014) }\end{array}$ \\
\hline P. monodon & 249 & 0.18 & $4 \times 10^{-3}$ & 3.218 & 0.966 & I & Sri Langka & Piratheepa et al. (2013) \\
\hline Acetes Sibogae & 53 & 0.14 & 0.001 & 3.403 & 0.931 & $A^{+}$ & Malaysia & Wong et al. (2015) \\
\hline Acetes japonicas & 74 & 0.12 & 0.005 & 2.883 & 0.850 & A- & Malaysia & Wong et al. (2015) \\
\hline Acetes serulatus & 381 & 0.20 & 0.009 & 2.749 & 0.829 & A- & Malaysia & Wong et al. (2015) \\
\hline Acetes indicus & 604 & 0.56 & 0.007 & 2.829 & 0.941 & A- & Malaysia & Wong et al. (2015) \\
\hline
\end{tabular}

The $K$ value 1.31 for Macrobrachium sp. from this study were slightly higher than $M$. rosenbergii (1.09) under rice fields (Kunda et al., 2008), Atya gabonensis (1.014) from river (Okayi and lyorkyaa, 2004) or P. monodon (0.727) under cultured (Gopalakrishnan et al., 2014). Meanwhile, the K values of $0.36-$ 1.56 for fish are also commonly found in some fish species from other habitats. These values showed that most of the species in this river were in good condition. Variation in the value of the mean $K$ may be attributed to biological interaction involving intraspecific competition for food and space (Arimoro and Meye, 2007) and the difference in aggressive behaviour (Deekae and Abowei, 2010) between shrimps. On the other hand, the factors affecting the variation values of $K$ may include sex, stages of maturity, and state of stomach contents (Gayanilo and Pauly, 1997; Abowei et al., 2009).

For internal evaluation, the use of incandescent squid fishing tackle with diamond shape in its surface (e.g. SIL-1, $0.45 \mathrm{~W}$ ) in Experiment 1 was able to increase the distribution of the amount of lights and showed an equal effective to the acrylic box-shaped lamps with all directional luminous (Dimmed/Lighted, $4.5 \mathrm{~W}$ ). The SIL-1 or SIL-2 seemed to be more effective when operated in clear water than turbid water. Whenever they are applied in turbid water the use of higher intensities is recommended and the results are still open for discussion. The use of acrylic box-shaped lamps for sampling Macrobrachium sp. from Barito River is reflected to be similarly effective for catching American crayfish (Procambarus clarkii) from a pond in Japan (Ahmadi et al., 2008).

It is beyond our expectation that acrylic-square light traps in Experiment 4 were only used for one night fishing due to impracticability during their operation. The acrylic entrance slits apart from the trap body because of losing adhesiveness when soaked and from water pressure. In consequence of this problem, the traps caught insignificant number of juvenile shrimp and none of fish was caught. Acrylic-square trap was initially tested in indoor tank belonging to the Faculty of Fishery, Kagoshima University Japan and had some success in catching the juvenile of $P$. clarkii. We used the trap to pronounce their exploratory behaviour in the tank under lightadapted conditions, and later explored to collect the animal from a pond (unpubl. data). For further use, a redesign of the current acrylic-square trap is required to improve the function of its catch efficiency.

In summary, trapping with low-powered underwater lamps is applicable in high turbid water of Barito River. The colours of lights had strong effects on the number of shrimp collected. The size and shape of the light traps did not affect number of catch. The use of LEDs is considered more advantage than incandescent bulbs, because they are more energy efficient, more colours available, and more durable. For further research, it is necessary to determine which important species to be targeted by the lighted traps, so that the issues on the bycatch could be pointed out.

\section{ACKNOWLEDGEMENTS}

This research was under our own means of funding. The author is grateful to Mr Ahmad Rizani and Mr. Yusuf for their support during the trapping experiments and thanks Mrs. Siti Ubaidah and Mrs. Tien Zubaidah for resultant measurements. The author also thanks reviewers for significantly improving the quality of paper to a publishable level. 


\section{REFERENCES}

Abowei, A. F. N., Davies, O. A., \& Eli, A A. (2009). Study of the length-weight relationship and condition factor of five fish species from Nkoro River, Niger Delta, Nigeria. Current Research Journal of Biological Sciences, 1 , 94-95.

Ahmadi; Kawamura, G., \& Archdale, M. V. (2008). Mechanism of phototaxis in American crayfish, Procambarus clarkii (Girard, 1852) following different methods of trapping. Journal of Fisheries and Aquatic Sciences, 3, 340352.

Ahmadi. (2012). An introduction of light traps for sampling freshwater shrimp and fish in the Barito River, South Kalimantan. Journal of Fisheries and Aquatic Sciences, 7(2), 173-182. doi:10.3923/jfas.2012.173.182

Anderson, R. O., \& Neumann, R. M. (1996). Length, weight, and associated structural indices. In B. R. Murphy and D. W. Willis (eds), Fisheries Techniques (p.447-482). Bethesda, Maryland: American Fisheries Society.

Ara, M. G., Nobi, M. N., Ahmed, Z. F., \& Fatema, M. K. (2014). Length-weight relationship andgrowth pattern inference of a small indigenous freshwater prawn, Macrobrachium lamarrei (H. Milne-Edwards, 1837) in Bangladesh. Research in Agriculture, Livestock and Fisheries, 1, 137-145.

Arimoro, F. O., \& Meye, J. A. (2007). Some aspects of the biology of Macrobrachium dux (Lenz, 1910) (crustacea: decapoda: natantia) in river Orogodo, Niger Delta, Nigeria. Acta Biology Colombia, 12, 111-122.

Arimoto, T., Glass, C. W., \& Zhang, X. (Eds). (2010). Fish vision and its role in fish capture. Behavior of Marine Fishes: Capture Processes and Conservation Challenges. Ames, lowa (US): Willey-Blackwell.

Asyari. (2006). Characteristic of habitat and fish species at some fishery sanctuaries in the stream of Barito River, South Kalimantan. Indonesian Journal of Fisheries and Aquatic Sciences, 13, 155-163.

Baskoro, M. S., Murdiyanto, B., \& Arimoto, T. (2002). The Effect of Underwate illumination pattern on the Catch of Bagan with Electric Generator in the West Sumatera Sea Waters, Indonesia. Fisheries Sciences, 68(sup2), 1873-1876.doi: 10.2331/fishsci.68.sup2_1873

Brogan, M. W. (1994). Two methods of sampling fish larvae over reefs: comparison from the Gulf of California. Marine Biology, 118, 33-44.

Chow, S., \& Sandifer, P.A. (1991). Differences in growth, morphometric traits, and male sexual maturity among pacific white shrimp, Penaeus vannamei, from different commercial hatcheries. Aquaculture, 31, 165-179.

Deekae S. N., \& Abowei, J. F. N. (2010). Macrobrachium macrobrachion (Herklots, 1851) length-weight relationship and Fulton's condition factor in Luubara creek, Ogoni land, Niger Delta, Nigeria. International Journal of Animal and Veterinary Advance, 2, 155-162.

Dineshbabu, A.P. (2006). Length-weight relationship and growth of the speckled shrimp Metapenaeus monoceros (Fabricius) off Saurashtra. Journal of Marine Biological Association of India, 48(2), 180-184

Faller, M., Maguire, I., \& Klobucar, G. (2006). Annual activity of the noble crayfish (Astacus asutacus) in the Orljava River (Croatia). Bulletin Français de la Pêche et de la Pisciculture, 383, 23-40.

Gautam, K., Nazar, A.R., Anand, E., Ganesh, Mahendran, S., \& Mahadevan, G. (2014). Study of length and weight relationship of Litopenaeus vannamei (Boone, 1931) from East Coast of India. International Journal of Science Inventions Today, 3(4), 365-376

Gayanilo, F. C., \& Pauly, D. (1997). FAO-ICLARM Stock Assessment Tools (FiSAT). FAO Computerised Information Series (fisheries) Number 8. Rome, p. 262

Gopalakrishnan, A., Rajkumar, M., Rahman, M. M., Sun, J., Antony, P. J. Venmathi maran, B. A., \& Trilles, J. P. (2014). Length-weight relationship and condition factor of wild, grow-out and 'loose-shell affected' giant tiger shrimp, Penaeus monodon (Fabricius, 1798). (Decapoda: Penaeidae). Journal of Applied Ichthyology, 30, 251-253.

Hernandez, F. J., \& Shaw, R. F. (2003). Comparison of plankton net and light trap methodologies for sampling larval and juvenile fishes at offshore petroleum platforms and a coastal jetty off Louisiana. In D.R. Stanley and
A. Scarborough-Bull (eds), Fisheries, Reefs and Offshore Development (pp. 15-38). American Fishery Society Symposium.

Holdich, D. M. (Ed.). (2002). Biology of Freshwater Crayfish. Oxford: Blackwell Science, p. 702.

Hortle, K. (1995). A survey of the Barito River fishery near Mount Muro, Central Kalimantan, Indonesia. Tropical Limnology, 3, 15-27.

Hua, L. T., \& Xing, J. (2013). Research on LED Fishing Light. Research Journa of Applied Sciences, Engineering and Technology, 5(16), 4138-4141.

Kissick, L. A. (1993). Comparison of traps lighted by photochemical or electric bulbs for sampling warmwater populations of young fish. North American Journal of Fisheries Management, 13, 864-867. doi: 10.1577/1548-8675(1993)013<0864:COTLBP>2.3.C0;2

Kunda, M., Dewan, S., Uddin, M. J., Karim, M., Kabir, \& Uddin, M. S. (2008) Short Communication: length-weight relationship, condition factor and relative condition factor of Macrobrachium rosenbergii in rice fields. Asian Fisheries Science, 21, 451-456.

Lalrinsanga, P.L., Pillai, B.R., Patra, G., Mohanty, S., Naik, N.K., \& Sahu S. (2012). Length weight relationship and condition factor of giant freshwater prawn Macrobrachium rosenbergii (De Man, 1879) based on developmental stages, culture stages and sex. Turkish Journal of Fisheries and Aquatic Science, 12, 917-924.

MacKinnon, K., Hatta, G., Halim, H., \& Mangalik, A. (1996). The Ecology of Kalimantan: Indonesian Borneo. Periplus, p. 872

Marchetti, M. P., Esteban, E., Limm, M., \& Kurth, R. (2004). Evaluating aspects of larval light trap bias and specificity in the Northern Sacramento river system: Do size and color matter?. American Fisheries Society Symposium, 39, 269-279.

Matsushita, Y., Azuno, T., \& Yamashita, Y. (2012). Fuel Reduction in Coastal Squid Jigging Boats Equipped with various Combinations of Conventional Metal Halide Lamps and Low-Energy LED Panels. Fisheries Research, 125-126(0), 14-19. doi: 10.1016/j.fishres.2012.02.004

Mills, E., Gengnagel, T., \& Wollburg, P. (2014). Solar-LED alternatives to fuelbased lighting for Night Fishing. Energy for Sustainable Development, 21, 30-41.doi: 10.1016/j.esd.2014.04.006

Nwosu, F.M., \& Wolfi, M. (2006). Population Dynamics of the Giant African River Prawn Macrobrachium vollenhovenii Herklots 1857 (Crustacea, Palaemonidae) in the Cross River Estuary, Nigeria. West Africa Journal of Applied Ecology, 9, 1-14.

Okayi, G., \& lorkyaa, A. (2004). Length-weight relationship and condition of freshwater shrimps Atya gabonensis and Macrobrachium felicinium from the Mu river, Makurdi, Nigeria. Animal Research International, 1, 153-154.

Prasetyo, D., \& Asyari. (2003). Inventory of fish species and characteristic of Bartio River. In Proceedings of Expose of Research Result (pp. 37-42). Jakarta: The Research Centre for Capture Fisheries - Agency for Marine and Fisheries Research - Ministry of Marine Affairs and Fisheries.

Prasetyo, D., Asyari, \& Sudrajat, A. (2005). Inventory of fish species and habitat characteristics of Barito River waters, South Kalimantan and Central Kalimantan. In Proceeding of Indonesian Inland Fishery Forum (pp. 339346). Jakarta: Research Center for Fisheries Management and Fish Resource Conservation

Puspito, G., Thenu, I. M., Julian, D., \& Tallo, I. (2015). Utilization of light-emitting diode lamp on lift net fishery. AACL Bioflux, 8(2), 159-167

Rahman, A. (2008). Study on abundance and diversity of typical planktons at estuary river of Kelayan. Al 'Ulum, 36, 1-6. (Indonesian with English in Abstract).

Richards, C., Kutka, F. J., McDonald, M. E., Merrick, G. W., \& Devore, P. W. (1996). Life history and temperature effect on catch of Northern Orconectid crayfish. Hydrobiologia, 319, 111-118.

Rosadi, E., Yuli, E., Setyohadi, D., \& Bintoro G. (2016). Native Species in Barito Upstream at South Kalimantan, Indonesia: sex ratio and length-weight relationship of Seluang Batang Fish (Rasbora argyrotaenia Blkr, 1850). Journal of Wetlands Environmental Management, 4(2), 84-90. doi: $10.20527 /$ jwem.v4i2.55 
Rupawan. (2006). Specification, operational way and gear selectivity of gillnet on Barito River. In Proceeding of National Seminar on the Third Indonesian Inland Fishery Forum (pp. 44-55), Palembang. (Indonesian with English in Abstract).

Sampaio, C. M. S., \& Valenti, W. C. (1996). Growth curves for Macrobrachium rosenbergii in semi-intensive culture in Brazil. Journal of World Aquaculture Society, 27, 353-358.

Short, J. W. (2000). Systematics and biogeography of Australian macrobrachium (Crustacea: Decapoda, Palaemonidae) - with descriptions of other new freshwater Decapoda. Ph.D Thesis. Australia: University of Queensland.

Utomo, A. D., \& Prasetyo, D. (2005). Catch evaluation of several fishing activities at Barito River, South Kalimantan and Central Kalimantan.
Journal of Indonesian Fisheries Research, 11, 1-22.

Utomo, A. D., \& Asyari. (2007). The fishing gears selectivity at Barito River, South Kalimantan and Central Kalimantan. In Proceeding of National Seminar on the fourth Indonesian Inland Fishery Forum (pp. 31-35), Palembang. (Indonesian with English in Abstract)

Wong, B.Y., Ong, H.K.A., \& Khoo, G. (2015). Length-Weight Relationships of Acetes spp. sampled along the West Coast of Peninsular Malaysia. Sains Malaysiana, 44(3), 379-386

Yamashita, Y., Matsushita, Y., \& Azuno T. (2012). Catch Performance of Coastal Squid Jigging Boats using LED Panels in combination with Metal Halide Lamps. Fisheries Research, 113(1), 182-189.

doi: 10.1016/j.fishres.2011.10.011. 